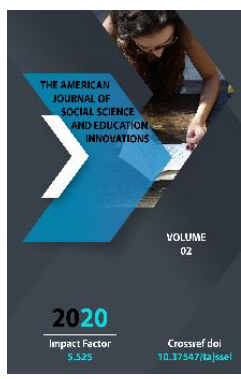

Copyright: Original content from this work may be used under the terms of the creative commons attributes 4.0 licence.

\section{Preservation Of The Originality Of The Work Of Art In Translation}

\author{
Komila Rishatovna Babayeva \\ Senior Teacher At The Department Of English, Tsue, Uzbekistan \\ Gulnoza Utkurovna Istamova \\ Senior Teacher At The Department Of English, Tsue, Uzbekistan
}

\title{
ABSTRACT
}

The phraseological structure of the language has a wide meaning and stylistic nuances. Phraseology is often seen as a branch of lexicology. Because phraseology is the equivalent of words in a language, and lexicology is the study of the words that make up the vocabulary of a language and their equivalents. Sometimes phraseology is incorporated into lexicon or stylistics. With phraseology, words should not be viewed as completely equivalent.

\section{KEYWORDS}

Form, meaning, dictionary, figurative expression, component, phraseological unit, charm, image, idea.

\section{INTRODUCTION}

Phraseologisms as well as the structure and meanings of words have many distinguishing features, and their morphological and syntactic functions also vary. According to their content, words are formed as a whole. both semantic types of phraseology (phraseological integrity and phraseological confusion) are explained by the semantic connection of their components, the stability of the morphological and syntactic combination of lexical composition in many places. Phrases and components of sentences, on the other hand, have more freedom in semantic connection.

\section{THE MAIN RESULTS AND FINDINGS}

For this reason, phraseologies are called fixed combinations, and phrases and sentences are called free combinations according to their content.

By studying the semantic features of phraseologies, it was found that they have the 
phenomena of phraseological polysemia, phraseological synonymy, and paronomy. The paradigmatic and syntagmatic features of phraseologies show their widespread use of grammatical (morphological, syntactic) and lexical-semantic means. The variation of phraseologies depends on the substitution (substitution), addition, omission, and transformation of their components.

According to the grammatical (morphological) structure, phraseological verbs such as verb, horse, form, preposition, etc. are distinguished.

It is necessary to emphasize the group of phraseological units associated with human names, that is, with the onomastic component. Within this group, the following three sections can be distinguished.

1) onomastic phraseological units related to surnames,

2) phraseological units with onomastic component related to nouns,

3) phraseological units with an onomastic component associated with first and last names.

The main part of the phraseological units with the onomastic component is semantically oriented to the person, they assess a person's physical, mental, moral, intellectual characteristics, behavior. Phraseologically stable compounds with an onomastic component in English are inextricably linked with the spiritual, national culture, customs, profession, living conditions, aspirations, attitude to reality of the English people. They are important tools for creating imagery, expressiveness, and serve to increase the expressive effectiveness of artistic and journalistic texts. They are concise, semantically sound, and help to express an idea in a grounded, figurative, and effective way.
Phraseological compounds with an onomastic component can be divided into two main groups according to their origin.

1) phraseological units with onomastic component specific to pure English, words coming from other languages

2) In turn, pure English words are grouped as follows.

- Bibleism,

- Shakespeareans,

- Phraseological units with onomastic components related to ancient mythology,

- Phraseological units with an onomastic component associated with the names of historical figures,

- Taken from literary sources (related to the names of the characters in the work) phraseological units with onomastic component.

- Compounds related to the customs of the English people,

- Compounds related to English realities.

Phraseologically stable units with an onomastic component coming from a foreign language can be grouped as follows.

1) phraseological units with onomastic component related to mythology,

2) Phraseological compounds with onomastic component coming from French.

3) Phraseological compound with onomastic component derived from German Phraseological compounds with onomastic component.

Phraseological combinations with onomastic components are used to animate the text, to make it attractive and figurative, to express the idea with ready-made text templates, formulas, to make it meaningful. Phraseological combinations with an onomastic component in English represent the national identity of the English people. The difficulty of reflecting them in translation 
is that they have a distinctly distinctive national character. Moreover, the complex nature of lexical, semantic-stylistic and compositional units of phraseological units with onomastic components poses additional difficulties for the translator. Preservation of the original phraseological structure in the translation is an important condition for the reconstruction of the figurative and emotional features of the work.

When translating phraseological units with English onomastic components into Uzbek, it is impossible to include all the elements of national identity, but it is necessary to keep among them so that the reader has an idea of the national environment of the people.

Giving the tone of a work of art in translation is important in all literary genres. If there is no harmony from a separate proverb or two to a sonnet, a ghazal, a poem, a story, a novel, then the translation sounds fake. The melody, in turn, connects the other components of the work of art, such as lexical unity, syntax, inversion, radif, rhyme, weight, and other means, giving translation and naturalness, or, conversely, falsity, i.e., artificial context, the emergence of an artificial artistic environment.

Style is a unique feature of each author, which requires each artist to have his own style - the ideological direction of his work, the artistic and visual means used in the text, lexical and phraseological elements and specific components related to the artistic form.

Re-creation of each author's own "language", ie style, is one of the important conditions of literary translation and requires great artistic skill from the translator.

\section{CONCLUSION}

The stylistic variety, the charm of form and meaning is a great treasure of every national literature. Were it not for the variety of styles and colors, there would have been a single stylistic ambiguity, ambiguity, ambiguity. Such a situation would have led to intellectual bluntness, artistic poverty. Therefore, the value of each national literature is measured not by the abundance of its literary output, but by the creative power of the creative mind that has created and continues to create its own free style patterns. This means that in determining the unique style of each artist, it is not necessary to compare his work with the style of poets and writers who lived in another historical period, but it is possible to compare the work of contemporary writers.

\section{REFERENCES}

1. Budagov R.A. Charles Balli and ego work on obshchemifrantsuzskomu yazykoznaniyu. M., 1962.

2. Weinreich U. Experience of semantic theory. -In the book. New in foreign linguistics, vol. X, M., 1981, $152-176$ pp.

3. Kudratov T. Nafasov T. Linguistic analysis. Tashkent, Teacher, 1984.

4. Kunin A.V. English phraseology. Moscow, Vysshaya school, 1970.

5. Lotman Yu.M. The structure of the literary text. Moscow, Art, 1970.

6. Mamatov AE. Problems of lexical and phraseological norms in modern Uzbek literary language. T. 1998.

7. Musaev K. Lexico-phraseological questions of the divine translation ", Tashkent, Teacher, 1980.

8. Muhammedjonova G. Some issues of Uzbek language lexicon development ". Tashkent, "Fan", 1982.

9. Mukarramov I. Scientific style of modern Uzbek literary language. Tashkent. Fan, 1984. 